\title{
MNX1/ETV6 Fusion Protein
}

National Cancer Institute

\section{Source}

National Cancer Institute. MNX1/ETV6 Fusion Protein. NCI Thesaurus. Code C105818.

A fusion protein encoded by the MNX1/ETV 6 fusion gene. This protein is comprised of the $\mathrm{N}$-terminal portion of the motor neuron and pancreas homeobox protein 1 protein, including the polyalanine repeat domain, fused to most of the transcription factor ETV6 protein, including the helix-loop-helix and ETS domains. 